\title{
The Institutional Framework of Post-Socialist Literary Production: Literature as Creative Writing
}

Een though the main sources of the drama (or tragedy, to be more precise) of the
capitalist restoration in former Yugoslavia (or "transition," as it is usually called) are its most visible socio-economic consequences such as deindustrialization, ethnic wars, forced population movements, or skyrocketing social inequality, the changes occurring to the seemingly less dramatic constituents of the system, such as cultural production, should by no means be disregarded. ${ }^{1}$ They should, however, be studied with a sharper critical and comparative focus on their systemic - institutional, political-economic - aspects, which are determined by pressures stemming from the realities of the social organization of production as a whole. This is necessary not only because such analyses are prerequisites for an informed understanding of specific cultural artifacts in their historical context but perhaps more importantly because they can shed light on the new types of hegemonic demands and limitations that are imposed on cultural activity, as well as ideological compromises that producers of culture are obliged to either internalize or at least consider and relate to in a necessarily political manner in order to have their work disseminated and understood in the public sphere.

As things stand at the moment, the existence of these ideological and institutional demands and limitations in the field of culture is visible only with difficulty, or when discussed, it is most often explained away as a consequence of temporary institutional disorder emerging from the chaos of transition and entirely corrigible by better policies. At its most abstract, the dominant contemporary ideological narrative (no matter whether deployed in its liberal pluralist or conservative nationalist version) of the emergence of the new national cultural fields in ex-Yugoslav countries is a familiar one: it considers the fall of Yugoslav socialism to be a "de-institutionalization" of sorts, a liberation of culture, public expression, and creativity in the successor republics from what is perceived as the stranglehold of the state and its institutional controls and ideological demands. As I hope to show in the following examination of what I consider to be crucial institutional changes to the literary field in one of the successor republics, not only does the establishment of such a facile dichotomy between "state" and "culture" make it more difficult to observe restrictive institutional mechanisms

\footnotetext{
The writing of this article was supported in part by the Croatian Science Foundation (HRZZ-1543). The article is based on an essay entitled "Od socijalizma do kapitalizma, od književnosti do kreativnog pisanja," originally published in the 2013 collection Političko-pedagoško: Janusova lica pedagogije (ed. Ivana Perica; Zagreb, Udruga Blaberon), and then revised, translated, and expanded into its current form.
} 
regulating cultural production in historical contexts where the state plays a less significant (or at least more indirect) role, but the implication that there is an essential opposition between the state and the cultural field crudely distorts a relation that is historically much more complex and varied.

\section{The Context of Capitalist Restoration}

It seems that the most recent capitalist crisis that hit peripheral European countries such as Croatia especially hard not only caused the institutional configuration of the post-socialist literary field to be revealed under strain, but also motivated new attempts to transform it in line with the realities of the completed transition. The necessity of coming to terms, post-transition and post-crisis, with the economic problems facing producers of culture has also created conditions for a new awareness of the political economy of cultural production under capitalism. After two decades of inertia, during which the systemic aspects of the post-socialist literary field and their problematic consequences - everything from multifaceted class alliances between new national cultural figures and post-socialist capital to the oligopolistic publishing market - were sometimes criticized but rarely addressed systematically or politically challenged, ${ }^{2}$ the dire situation seems to have finally provoked a change in this passive attitude during the six-year-long Croatian recession. Consequently, several initiatives addressing the perceived dysfunction of the field from fresh perspectives appeared. The two issues that have received the most attention during those last several years are the legal status of literary professions (i.e., the regulation of literary cultural labor in relation to the state) and the related issue of the academic institutionalization of literary writing. ${ }^{3}$ Besides simply functioning as pragmatic answers to concrete problems, both have in the public sphere been positively framed as attempts to "modernize" the literary field, to guarantee it, after the chaos of transition and the difficulties of the crisis, a new form of stability and continued existence as one of the safeguards of a number of cultural freedoms that in bourgeois societies function as, among other things, legitimizing agents of that particular socio-historical arrangement, as symbols of democratic, civilized maturity.

The fact that precisely these issues have motivated new initiatives and organizational efforts, or in other words, that precisely these issues appear as fundamental for

\footnotetext{
The exceptions to this trend indicate that the most productive genre for such criticism of the field has been more literary than academic: for instance, Borislav Mikulićs newspaper column in Slobodna Dalmacija collected in a book entitled Kroatorij Europe, the literary-philosophical essays of Boris Buden (Barikade), or Dean Duda's columns in Feral Tribune collected in the book Hrvatski književni bajkomat (see Buden, Duda, Mikulić).

3 It is important to note that the second issue, as in many other European countries, functions as an institutional innovation in the post-socialist context. Despite the decades-long history of institutionalized creative writing programs in, most notably, the United States and their normalization as a part of the academic field, no such institutional, pedagogical, or more broadly organizational model has existed in Croatia until recently.
} 
the functioning and reproduction of the literary field, is related to its reorganization in the processes of capitalist restoration. The material conditions that today determine the position and options of agents in the field, as well as the field's institutional protocols, did not exist in the same form prior to the post-socialist rupture. One of those conditions, a crucially important one, is the already mentioned publishing oligopoly - a small number of large publisher/distributors that have the power to control not only the distribution of books but also more or less directly what appears in print. A recent study has shown that about $85 \%$ of the Croatian bookstore network is owned by a few large publishers, meaning that a very small number of private companies "monopolizes the market, blocks the distribution of books, dumps prices, and establishes a damaging dynamics of payment for sold copies, while often limiting the offer of books by other publishers in its stores" (Bartolčić et al. 85). One of the many consequences of this state of affairs has been the absurdly low and irregular fees paid by publishers to their authors, many of whom have been forced into a position with no bargaining power in which they have the option either to accept the very low fee and have their book satisfactorily distributed by the publisher-distributor or to try to self-publish or find an independent publisher and get another very low or no fee at all, but without any guarantee of satisfactory distribution because the supporting network of independent bookstores has been forced out of business by the oligopoly. This in combination with other problems has led over the years to a situation where hardly any contemporary Croatian writers can count on satisfactory remuneration for their labor and cannot expect to live off writing alone even after they have achieved a significant level of visibility in the field and their sales figures are, at least in the context of the post-socialist literary field, quite high. But more broadly and most importantly, it is not reasonable to expect that cultural production will be regarded as anything but a luxury in a society that structurally limits access to culture to the majority of its citizens: in a peripheral Croatian economy, devastated in the processes of capitalist restoration (for the sake of comparison, the country's GDP in 2014 was 7.7\% lower than the GDP in 1986 after years of socialist crisis) (Domazet 2), the already low sales of books dropped even more drastically during the recessionary years that followed the 2008 global systemic crisis. There are no external empirical studies of this particular aspect of the publishing market, but as reported by the publishers themselves in 2012, the drop in sales between 2011 and 2012 amounted to 30-50\%, depending on the field and genre (Mikuličin). Expectedly, publishers and booksellers complain this can only be compounded by the fact that the state has reintroduced the Value Added Tax on books (it was raised from 0 to 5\% in 2013) in compliance with the EU regulations upon entering the Union (Piteša). And lest we forget-figures such as the average registered unemployment rate, which has long hovered not much below $20 \%$ (in 2015 it was $17.7 \%$ ), do not exactly help boost the demand for literary commodities production, either.

For the producers of literary texts-for writers - this has meant that, in the postsocialist period, neither could they count on making it in the weak(ened) post-socialist market, nor could they expect to lean on the state, which before 2005 offered no in- 
dividual programs of support for literary production, not even in the form of stipends or literary project grants, quite common elsewhere in Europe. Even though there have been some positive changes in this respect recently, and some of the above-mentioned professional initiatives have resulted in limited reform, such as the establishment of new grants and further opportunities for the public funding of literary production, with the continued emphasis on austerity as the inescapable model of grappling with recession and the post-crisis economic slump, this situation cannot be expected to improve with the help of the state in the near future and is in fact very likely to become worse. ${ }^{4}$

Working under these adverse conditions, Croatian writers have attempted to push for practical institutional reforms on the state level in order to reconfigure the institutional arrangement of the literary field to their benefit. The first step-and first limited victory-in this process was simply to publicly articulate some of the labor problems literary workers in Croatia face. The second step was to push for a reform of the legislative framework regulating the literary profession. In 2011-2012, Croatian writers, organized in the initiative "The Right to a Profession," fought for and achieved legal recognition of their profession and can now expect a certain degree of professional regulation and related benefits. This might be an important improvement for many, even though the dynamics of the field remain tied to the negative impact of its post-socialist transformations and the difficult socio-economic conditions sketched out above. But what I would like to concentrate on in more detail here is a narrowly related and seemingly spontaneous development that follows from this change in the legal status of the profession.

The idea is that after literary writing has been recognized as a profession within the legislative framework of the state, ${ }^{5}$ it is necessary to develop state institutions within which the profession can be fully practiced and credentialed. In an attempt to create these institutions, the proponents of the idea looked to the U.S. literary field in search of inspiration and an institutional model. Consequently, in the past several years serious effort was put into the project of establishing the first Croatian public university creative writing departments. It is important to note, however, that this development did not come out of the blue. "Creative writing" both as a concept and an institutional model entered the literary field through a network of informal (in relation to the state) writing workshops that started appearing some ten years ago. ${ }^{6}$ The

4 Indeed, it already has become worse: approved state support for book publishing for 2013 was $12.5 \%$ lower than in 2008. This drop increases to $19.1 \%$ when subsidies for literary journals and electronic publications, literary events, and literary programs in bookstores are added and taken as a whole. (For a detailed account, compare Croatian Competition Agency 2011, 2008)

5 As a result of the literary workers' initiative, the National Council for Science, Higher Education and Technological Development, the highest advisory body for scientific research, higher education and technology and a part of the Croatian Ministry of Science, Education and Sports, issued the new Ordinance on Scientific and Artistic Areas, Fields and Branches, a document regulating academic professions, which under the area of "art" now contains the field "literature," which includes two branches_-"writer" and "literary translator."

6 Perhaps the best-known creative writing workshops are organized by $\mathrm{CeKaPe}$, the Centre for Creative Writing, where a number of well-known Croatian writers have taught since 2007 when it was founded. 
best-known of the workshops are commercial, i.e. they are a platform for offering the experience and knowledge of established writers as a commodity. As such, their historical emergence cannot but be observed as a structural effect, a development within the broader context of the commodification of culture, leisure, and education under the conditions of post-socialist transition. As the workshops grow in popularity and become more entrenched, and as communication and resource exchange networks develop between participants, mentors, and others, the workshop model is becoming an important element of the literary field's institutional arrangement.

Thus it is unsurprising that the conceptual innovation that is creative writing as conceived by the workshops was seen as an integral part of the project of professional legislation described above. However, despite optimistic announcements, the project of academic institutionalization of the profession has not yet been realized. So far, no dedicated university departments, or even chairs, have been founded, and only several intermittent classes in creative writing have been offered in the modern languages departments at universities in Pula or Split. Nevertheless, the specific needs and problems the project was supposed to meet and provide answers to, together with the systemic conditions that motivated its emergence, still exist, and its rearticulation can most likely be expected in the future. An analysis of the logic and likely consequences of such institutional reforms that are lacking from cultural discussions in the post-socialist context is thus necessary and justified.

To limit this complex issue to something manageable in the format of this text, I would like to examine more closely the institutional history and ideological legitimation of the reforms promising to introduce academic credentialization of the literary professions, and the effect their consequences might have on what has been recognized, perhaps most notably in the work of Pierre Bourdieu ${ }^{7}$, as the defining principle of the literary field in bourgeois societies since the nineteenth century-the principle of artistic autonomy. Usually, without much historicizing effort, this principle is taken to be positive and immanent to literary-artistic practice, and is defined relationally, against "negative" socio-political entities that threaten its full expression. It is thus customary, from a post-socialist liberal perspective, to observe the socialist state (for good historical reason, no doubt) as the one that automatically comes to mind when we think of forces responsible for the curbing of artistic autonomy, whereas its guaranteed existence in capitalist liberal democracy is taken for granted. ${ }^{8}$ The truth is, however, not so unambiguous, especially in the case of socialist Yugoslavia and its

\footnotetext{
See Bourdieu 1995 for a historical study of the French literary field in which some of the conceptual tools this article relies on were developed and/or deployed.

8 In cultural-theoretical discussions, "autonomy" is often conceived in several different ways: a) as a defining characteristic of the literary field emerging from the complex social interactions in bourgeois modernity along with other related phenomena such as secularization or democratization; b) as a historical politicalaesthetic attitude $-\mathrm{a}$ (proto)modernist cultural credo of emancipation from bourgeois commercialism and materialism; c) often, especially in the post-socialist context, it is also simply conceived as a relation to the state - a political right of the cultural producer to freedom from political proscription and censorship.
} 
capitalist successor-republics. In order to explain what I mean, a broad historization of this problem is necessary.

\section{Socialist Modernity}

Literary historians often refer to Miroslav Krležàs speech at the 1952 Writers' Congress in Ljubljana as one of the central symbolic moments through which the fundamental ideological coordinates of the Yugoslav literary field - its specific ethos, role, and position within society - were determined. The speech was not only the final word in a twenty-year-long polemic on the social function of literature that has become known as the "Conflict on the Literary Left," but also a public denunciation of Stalinism and the Stalinist-Zhdanovian model of state-directed cultural production. By sharply criticizing Stalin, Krleža was certainly acting in accordance with his role as the leading cultural figure in Titoist Yugoslavia, but he was also simply reiterating and developing his old, unrelentingly modernist ideas about the necessity of autonomous cultural production and the freedom of the field of art from dictates whose logic is foreign and hostile to its development, irrespective of whether those dictates are commercial, religious, or political. Krležàs strong and consistent position on this matter not only helped, but provided strong wind for the sails of post-war Yugoslav literary and cultural production in general, and was enthusiastically received by younger generations of authors. Thus it occurred, for instance, that the symptomatic title of an editorial written by Vlatko Pavletić for the first issue of the literary journal Krugovi [Circles]— "Neka bude živost" [Let there be liveliness] —was taken up as a motto for the post-war generation of writers gathered around that journal. This aesthetic liberalism ${ }^{9}$ (together with all the material limitations, political censorship, and state control that were still practiced despite variation in strictness during different periods) developed in step with the institutional reforms in other fields that were gradually introduced after the 1948 Yugoslav break with the Soviet Union and the expulsion of Yugoslavia from the Cominform. It is precisely the compatibility, or complementarity, of the democratic aspects of the Yugoslav system of self-governing socialism with the modernist ethics of autonomy argued for by Krleža that could lead people like Edvard Kardelj, one of the architects of the new system and for decades one of the chief Yugoslav party officials, to pronouncements such as the one issued as early as 1954 in a speech at the Third Congress of the Union of Serbian Communists: "it seems to me that this work can

9 To mention in passing: as it cannot be denied that such developments have given rise to the conditions for the creation of some of the most important literary texts and movements of Croatian (and more broadly, Yugoslav) literature, it is interesting to note that many literary authors in Croatia who benefited from those developments, despite in some cases first being shunned or condemned by the less liberal cultural politics of the immediate post-war period, and whose key works could be produced and canonized precisely because of the specific nature of the relatively liberal Yugoslav system, later opted for politically deeply conservative as well as aesthetically anti-autonomist nationalist options during the process of the breakup of Yugoslavia in the late 1980s and 1990s. Some of these people are the already mentioned Vlatko Pavletić, as well as Vjekoslav Kaleb, Slobodan Novak, Petar Šegedin, Dubravko Horvatić, and others. 
succeed only if it rests on the initiative of the people who are personally connected to these forms of cultural production. Therefore, I think it is necessary to work toward a greater independence of educational and cultural organizations among the working masses, as well as toward connecting them vertically and democratically" (Kardelj 17). ${ }^{10}$ By the —at least for the contemporary horizon of political possibility-unusual term "vertical democratic connection," Kardelj means the linking of ineffective local (primarily the poorly developed rural) party, trade-union, and other cultural organizations that were prone to bureaucratization and dependent on inert procedures and alienated committees with other cultural and educational organizations that had achieved a satisfactory level of "self-governance" and mutual cooperation beyond local levels. The aim of this linking of cultural and educational organizations, and of the seemingly paradoxical process of gaining independence through attaching to others, is the transfer of knowledge and experience, cultural exchange, and education, as well as, ultimately, the creation of conditions for the autonomous development of cultural institutions and cultural production that responds to the concrete historical needs of the people in the community. In the same speech, Kardelj goes on:

Consequently, ... it would be completely pointless if the Party itself advocated a this or that "-ism." This is a matter of cultural production itself. It will conquer the crisis and find a corresponding artistic form if it is an expression of the life and striving of today's generations in their fight for social progress. This is a conviction that we as communists have and must have, and we have to fight for it. This does not mean that we have to proscribe the content, themes, or form of cultural expression. Even if we wanted to, we would accomplish nothing by such meddling. This was in his time already attempted by Stalin with his rules of "socialist realism," and he only managed to prove that decadence can be expressed in that form too. (Kardelj 19)

And even though Kardelj in the quoted speech also espoused conservative beliefs about the corruptive influence of comic books and jazz music ${ }^{11}$ and made contradictory statements that left much theoretical room for the possibility of direct political intervention and censorship in cultural production, this is the theoretical foundation upon which later systemic measures discussed by him in a speech at the opening of the Belgrade Book Fair in 1975 were created. In that speech, following a couple of decades of Yugoslav institutional and political experimentation with self-governance and the socialist market, as well as a major constitutional reform in 1974, he focused on the perceived social need to make access to books and literature as easy as

10 Most of the texts quoted in this essay have not been translated into English. Unless otherwise noted, the translations given here are mine.

11 These sometimes come across as caricatures of the arguments of the Frankfurt School on capitalist mass culture, and would, in their cultural elitist aspect, have hardly been uncharacteristic of senior political officials of any state at the time. 
possible. He reiterated that the constitutional reforms establishing the self-governing organizations in Yugoslavia opened up the possibility to solve particular problems autonomously, within the specific common interest bodies to whom those problems were of concern: "either within the framework of the self-management community of interests for culture, or within the framework of the autonomously organized, specific self-management community of interests for publishing; and with the participation and responsibility of the publishing industry, organizations of authors, organizations of associated labor, as well as the socio-political communities and organizations, and maybe other factors, such as libraries and others" (182). He added, importantly, that "problems cannot be solved only by subsidies. There is also a need ... for better organized engagement of society to help the book" (182). The possible ways in which the proposed engagement of society to destroy barriers to accessing culture can materialize are mentioned in passing in the remainder of the speech. All of them are based on proposals to activate autonomous associations of labor and connect local community organizations and their diverse cultural institutions through common initiatives as opposed to- this is especially interesting if we have in mind that the Yugoslav society was structurally dependent on commodity production and the socialist market-simply strengthening the publishing industry reliant on individual consumption.

Such policies and initiatives should not only be read as attempts to decentralize the production of culture in relation to the state (decentralization was one of the functions of the institution of the "self-management community of interests" and other similar elements of the Yugoslav system of self-governance), but also as nothing less than calls to institutionalize the conditions of possibility of the modernist ideal of the truly autonomous field of art. (Or more precisely and fundamentally, the communist ideal of labor-cultural labor in this case-autonomous from capital and the state.) In this regard, Yugoslav experimentation should be taken and studied very seriously, regardless of the project's flaws and structural limitations as exhibited through often contradictory historical experience. Its most important aspect is the implication that the conditions of possibility for artistic autonomy are not to be confused with either the cultural market or the self-exile of alienated spiritual aristocracies, but can be created only institutionally, by de-commodifying cultural production in an egalitarian society guaranteeing universal access to culture.

In contrast to the above institutional conception of autonomy, the canonical intellectual forbears of modernist autonomist radicalism, such as Flaubert or Baudelaire, who are often invoked as paragons of autonomy, were able to rely only on the individualist, perhaps even subcultural, ethics of autonomy. Their self-identification as artists and the pursuit of their artistic practice were in principle negative- they depended on the opposition to and disassociation from the bourgeois institutional order and on what they perceived as self-exclusion from any society except the one forming the great canon of the field. As Flaubert concisely puts it in a letter to his mother, "I am resigned to living as I have always lived, alone, with my crowds of great men as my only companions ..." (Flaubert 161) The Yugoslav example, in contrast, offers an interesting attempt to institutionally guarantee autonomy of cultural production as 
the central organizational principle of the literary field while still attempting to view literature as a productive activity with an important social function and producers of culture as integral parts of society. As Kardelj's statements quoted above show, this does not necessarily entail tying cultural producers to an official poetic doctrine. Such a position is based on a progressivist-humanist belief, common to both Kardelj and Krleža and exhibiting a considerable amount of revolutionary optimism, that leaving space for various aesthetic tendencies and related ideologies to battle it out on their own, without external interference, will lead to the victory of what Kardelj calls "truly artistic, scientific, humane ideas and values of our socialist society" (184).

It is precisely this belief, this particular openness of the system and parts of its bureaucracy, that made it possible for the later generations of Yugoslav authors-especially those who were maturing during Yugoslavia's final decade and became culturally dominant in post-socialist Croatia (e.g., the authors from the so-called "Quorum generation" and others) — to develop their postmodern, Western-pop-culture-influenced, sometimes self-indulgently aestheticist or self-referential cultural projects. One of the more important poets of that generation, as well as an important critic, publisher, and editor, Branko Čegec, could thus write in a 1983 essay on "the avant-garde and postavant-garde developments" that, at the contemporary historical moment the "ideologically self-aware authorial instance abandons the literary orientation burdened by the notion of the text as a battlefield of ideas and, by reevaluating fundamental literary aims, turns its interests instead towards the analysis of the external and internal laws ... of the literary text" (Čegec 6-7). It is very important to note that these proclamations come from a cultural figure who was on the editorial board of the journal published by the Association of Croatian Socialist Youth, or to put it more clearly—an "official" publication directly linked to central institutions of the state. This example of aestheticist radicalism at the heart of the establishment is enough to put to rest the superficially ideological assumption (often reproduced when post-Cold-War ideological pieties are observed and episodes from the complex history of "really existing socialism" are lumped together under the label "communist totalitarianism") that literary propagandism in the Yugoslav socialist period could be avoided only at personal risk, if an author was willing to jeopardize their social status or perhaps even their freedom due to pursuing aesthetic projects that could not be seen as promoting official doctrines or state policies.

\section{Transition from the Transition}

It is partly because of the inheritance of relative comfort of such a position within the system, ideologically legitimized by the socialist cult of education and culture, that it took so long after the breakup of Yugoslavia for post-socialist Croatian writers to wake up to the realities of their situation in the "transition". ${ }^{12}$ As Robert Perišić, one

$\overline{12}$ This could probably be extended to cultural producers in other artistic fields, as well. The early history of transition is marked by a curious lack of self-reflection and systemic criticism in the cultural sphere, with rare exceptions. 
of the most visible contemporary Croatian writers and the spokesman of the abovementioned "Right to a Profession" initiative, sarcastically wrote,

During this whole process, the writers were victims who, you know, watched from the sidelines, as eternal part-time workers and individualists, thinking none of this had anything to do with them, even though they had to realize before long that books weren't really being printed, and that, even when they were, there were no places to sell them (the network of booksellers having been devastated by privatization), so they were told that this is the reason why their own fees, this tiny right of theirs, were now gone. Because now they were "in the market," and the market, what do you know, ain't working at the moment. (Perišić)

During the two post-socialist decades, especially in the latter part of the '90s and early 2000s, the last socialist literary generation was thus critically engaged with the epiphenomena of the transition, such as nationalist cultural kitsch, while the structural changes threatening the bare existence of their practice and profession quietly (at least for those privileged enough not to be existentially threatened by this) unfolded in the background. During that time, the main weapons against the intellectual and poetic mannerism of the ethnonationalists were radical literary minimalism, so-called reality prose (the model for which was found in the very influential Raymond Carver), and the subcultural ethos of the "independent" part of the literary field, created in the tradition of punk festivals and the DIY scene and institutionally integrated into the civil society liberal framework established in the transition. For that part of the field, the principles of autonomous production were still central and carefully guarded, and to defend them meant also to distance oneself from the politics of ethnonationalists, who viewed "Croatian literature" as national first and literature second. ${ }^{13}$

But with the normalization of capitalist social relations and ideologies on the EU post-socialist periphery, with the (illusory) signs of waning of right-wing nationalism ${ }^{14}$ and the imminent Croatian accession to the EU becoming the order of the day-or, in other words, with the transition complete-this "marginalist" attitude towards autonomy also started to change. Under the conditions of finalized capitalist restoration, which in practice meant exposure to the capitalist market in a period of serious economic crisis and reduced availability of public support for cultural production (i.e., the infamous "austerity"), there occurred a spontaneous turning to institutional models and frameworks for literary production already tried out in the

13 Referring to my earlier note- on the surface, this seems to be a rather contradictory development from the post-WWII flowering of literary late modernism that many of the "nationalists" were connected with in their youth. A more detailed analysis would, I wager, most likely uncover a form of continuity between the youthful modernist elitism and mature nationalist exclusivism of those cultural figures.

14 The most recent turns of events, as in the rest of Europe, have given rise to a newly radicalized and growing right wing for which even the 1990s nationalist ideological substrate seems too thin. 
"ordered societies" of the idealized West. Thus, as already mentioned, an institution new to the post-socialist field and without precedent in earlier models emerged in an attempt to "modernize" the field, eliminate some of the problems that had emerged in the transition, and update modes of organization and communication within the field by adapting to the realities of capitalism on the EU periphery. This institution is known as creative writing.

\section{From Socialism to Capitalism, from Literature to Creative Writing}

I use the term creative writing here to signify an institutional arrangement of the literary field in which the academic writing program or creative writing workshop and their related sets of pedagogies and cultural practices become central frameworks of pedagogic exchange, communication, and literary production. Additionally, in the context of this particular analysis, the term also serves as a literary-historiographic orientation point marking a distinct phase in which the old public, autonomy-focused, social-democratic "literature" is displaced by "creative writing," a more market-oriented framework emerging under the conditions of capitalist universality and postsocialist transition.

As already mentioned, the two institutional forms "creative writing" took in Croatia are the older semi-formal creative writing workshop (offered in the context of civil society and the cultural market as a service that aspiring creative writers can pay for) and the creative writing university program (potentially offered, so far, only in public universities). In order to understand how this particular transformation of the field facilitates abandoning the principles of autonomous literary production in an attempt to integrate the field into the capitalist market, or in other words, to demonstrate how, far from being a guarantee of autonomy of cultural production as it is often suggested in the post-socialist context, "the market" leads to an effective eradication of autonomy, it is useful to examine how a creative writing university program was recently conceived in Croatia.

In the words of its creators, Natalija Grgorinić, Ognjen Rađen, and Marinko Koščec, the program was ready for certification and enrolling students as early as 2013 (Mandić), but for whatever combination of reasons, its implementation is still on hold in early 2016. This particular initiative remains significant, however, because it represents the most serious post-socialist attempt to institutionalize the creative writing model. If successful, it would achieve an institutional integration of the literary and academic fields in the context of the Bologna university reform. Having these institutional coordinates in mind, or in other words, having in mind the Bologna reform's role in preparing the university for subsumption under capital and its emphasis on skills-based education that "communicates with the market," it is unsurprising that Marinko Koščec announced that what would be taught in the creative writing program besides "literary" writing is what he calls "various forms of 'applied' written creativity." The ultimate purpose of the program, he goes on, would be to "produce a quality labor force for a myriad of activities" (Kolanović). 
His colleague Natalija Grgorinić goes even further, saying that "Our aim is to produce professionals who would be able to work with any form of text, including, of course, various literary genres-short stories, novels, poems - but who could also write speeches for politicians or write economic reports, and we could also train people who could work in the media, state administration, etc." (Mandić). Thus the most thorough recent attempt to transform the post-socialist literary field amounts to a capitulation of the previously dominant principle of autonomy and modernist ideologies of the aesthetic before the new institutional order of post-socialist society. This, of course, within the given framework, comes as no surprise, and the program's creators respond quite expectedly when asked to legitimize their project: the creative writing program in the new university can structurally hardly be anything more than what its creators say it is - a mechanism for the production of a specific type of labor power and in-demand cultural commodities. One consequence of this change, as announced by Grgorinić, would also be the quite radical reconceptualization of the role of the writer. Instead of the Romantic activist-poet in search of the sublime, the analytically detached social scientist of the realist novel, or the self-exiled modernist Künstler whose only allegiance is to art, the creative writer becomes an efficient professional, the mythical contemporary "expert" trained in literary technique, useful in a "myriad of activities" where a market for some form of persuasive public communication, rhetorical savvy, or entertainment might exist. In other words, if we want to uphold the somewhat tired distinction between autonomous art and instrumentalized propaganda, there is no doubt that the creative writer as conceived by the post-socialist pioneers of academic creative writing is a propagandist. Laid out like this, there is nothing to distinguish the logic of this sort of instrumentalist thinking as it relates to the autonomy of cultural production from the aforementioned Stalinism against which Krleža and other Yugoslav intellectuals riled 60 years ago. Both of these positions, Stalinist and post-socialist, discard the principle of autonomy ${ }^{15}$ and tie the dynamics of cultural production to heteronomous systems of legitimation and control (be they the state or the market, or both).

The uncomfortable truth about the structural integration of creative writing institutions and the capitalist market might be one of the reasons for common expres-

\footnotetext{
15 It is perhaps superfluous to mention that "autonomy" as invoked in this text cannot mean either "freedom from all constraints" or the possibility of exclusion from the terrain of history / class struggle, and does not imply an illusory aesthetic exceptionalism or an apolitical aesthetics. Cultural production is immanently constrained on several levels: by the influence of immediate material and broader socio-historical conditions in which it is situated, by the unavoidable fact that it is a social practice in need of a type of communal consensus in order for what is produced to find reception, etc. In addition, the concept of autonomy assumes a different meaning and political aims in different historical situations. The concept of autonomy in the context of the contemporary discussion about post-socialist creative writing is not quite the same as the concept of autonomy referred to, for instance, at the time of the Conflict on the Literary Left. Thus, to offer a contemporary working definition, let us for the purpose of this analysis use a simple, Utopian one: autonomy as cultural production outside the capital-relation.
} 
sions of doubt about the value (or at least pedagogical potential) of creative writing teaching. The existence of this doubt suggests a lingering modernist elitism that is still a key ingredient of ideologies dominant in the literary field. The seemingly endless discussion about whether "writing can be taught" ${ }^{16}$ is thus not a discussion about success rates of specific educational techniques, but a discussion between contradictory conceptions of the writer as a socially symbolic figure and the political implications these conceptions carry. (In this context, it should certainly be noted that arguing for the characteristic creative writing conception of writing as technique is not simply to argue for the field's commercialization, but also to advocate a form of its democratization, as opposed to the elitism immanent to widely dominant modernist conceptions that conceive of writing as constant transgression of describable technique-and therefore, of course, fundamentally unteachable.)

In the Croatian case examined here, this precarious attitude towards creative writing, characterized by doubt and constant negotiation of the meaning and purpose of the project, can be found even among the ranks of the pioneers of its academic institutionalization. One important partner in the university creative writing project is the president of the Croatian Writers' Association, Nikola Petković, who expressed it quite openly: a few years ago, before he ran for the function for the first time and based his mandate, among other things, on the academic institutionalization of creative writing programs, he stated in an interview that the only thing he hadn't changed his mind about after years of teaching creative writing in the United States was the conviction "that creative writing workshops were rather ... pointless," and that in the United States they serve as "sinecures for poorly-selling authors who have to live off something." Their only purpose, according to Petković, is that, "when they are successful, they make young writers aware of the editor's role" (Pintarić). Similar doubts also plague other creative writing proponents. For instance, Tema, Branko Čegec's post-socialist literary journal, dedicated a 2013 issue to the topic of creative writing and the editorial written by Kristina Špiranec begins precisely with a personal history of doubt about the pedagogical potential of the creative writing workshop: "To be honest, I was always skeptical myself" (Špiranec 10). Instead of entering this discussion yet again, it would make more sense here to adopt a more dialectical position and question the framework of the discussion as such by stating two things: firstly, that the constant reiteration of this discussion is an obstacle to observing the institution of creative writing in its systemic dimension, and secondly, that the discussion is founded on a dilemma that is false. Undoubtedly, as any other human cultural activity, writing requires socialization into sophisticated cultural knowledge, the recognition of established traditions of cultural communication, and a consistent study of technique. It not only can, but has to be taught and learned-the proper question to ask concerns the structuration of this pedagogical exchange by social institutions developed for that

16 For an interesting US iteration of this discussion, or more precisely, a discussion of the value of "program fiction" see Elif Batuman's review of Mark McGurl's book "The Program Era” and McGurl's response. (Batuman 2010; McGurl 2010) 
purpose: how do they relate to the broader institutional framework of the societies they belong to and what sorts of pedagogical subjects they envision and are expected to produce. There are crucial differences between various institutions in which writing has historically been practiced, discussed, learned, criticized, and edited. Enlightenment literary salons, modernist bohemian cafés, U.S. John Reed Clubs, revolutionary writers' societies in the early USSR, or creative writing workshops on the post-socialist EU periphery—all of these fulfill a basic pedagogical purpose as social institutions, but the meaning / historical purpose of specific cultural forms produced within their frameworks and the broader socio-historical conditions in which they emerged differ in significant ways. The question, and the problem with creative writing, is therefore not whether the workshop is an efficient learning environment, but whether its pedagogy is sensitive to its own position as a historical institution and whether it is interested in seeing its own limitations (as limitations of the society in which it exists) and willing to work towards transcending them.

So far in the Croatian context this has obviously not been the case. Despite the proclaimed goals of providing an opportunity for literary workers to make their livelihood, creating an easy entry into the field for "enthusiasts," and focusing on what is perceived to be the modernization of the field, the institutional architecture of creative writing in its current form is, from a consistently critical perspective, a part of the problem and not a step towards a solution. Dedicated literary work, even if successful, has in the post-socialist years guaranteed to literary workers neither livelihood, nor an audience, nor the continued possibility of publication, nor even the pleasure of basic social recognition of the importance of cultural production within the symbolic order of society. The new academic creative writing programs approach these problems by redefining the entire purpose of the field ("if writing novels doesn't work, why not try writing speeches for politicians") and transforming the modes of sociality practiced within the field into market relations-thus proposing that the structural reasons for the field's dysfunction become the field's principles of operation. Furthermore, their promise of providing a framework for practicing the recently legislated profession is a rather limited one. It is quite illusory in the context of the EU periphery to expect that the program will be able to achieve anything more than providing a small number of public university posts for people willing (and able) to train students in writing copy. In turn, they will (undoubtedly for a substantial tuition fee) produce a professionalized cadre structurally vulnerable to precarization and unemployment. Such working conditions are, to be fair and having in mind the history of the literary professions in bourgeois societies, not really a significant change for either better or worse, but without the Utopian promise of autonomy of artistic labor, there really is nothing to distinguish creative writing from, say, corporate accounting.

It should also be added that even the workshop form, meant to operate as a gateway for entrance into the literary field, a socialization platform, and a place for exchanging ideas, advice, and possibly contacts in the publishing industry, also partially thrives on an illusion. Having in mind the state and the logic of the post-socialist publishing industry and its problems on the level of both supply and demand, the 
possibility of publication is for structural reasons virtually impossible for most workshop participants, notwithstanding the quality of their work or invested effort. As Kristina Špiranec's poll among workshop attendees in Zagreb published in the special issue of Tema indicates, about three fourths of the polled workshop attendees "intend to continue writing seriously," and almost 60 per cent "intend to send their manuscripts to publishers." Furthermore, what emerges from the same poll is that the social composition of attendees, especially as it relates to class and gender, is rather monolithic: $75 \%$ of the attendees have some form of tertiary academic education, with as many as $24 \%$ pursuing postgraduate degrees; $79 \%$ are employed and come from the Zagreb region (unsurprisingly, considering that the workshops are located in Zagreb), and only $12 \%$ of the attendees are male (although the workshop mentors named in Špiranec's account, many of whom are acknowledged writers, do not reflect this gender dynamic -6 out of 8 are men) (Špiranec $21-31$ ). Fifteen per cent report they consider writing "a hobby," 73 per cent "a need", 6 per cent consider it "fun," and a further 6 look upon it as "therapy." Despite the informal nature of the poll, a sketch that emerges from these figures suggests that the workshop seems to serve predominantly as a relief from work and an avenue for the self-expression of educated urban middle-class women. Of course, with the awareness of the need for systematic inclusiveness excised from post-socialist cultural institutions, as well as with the commercial nature of the workshop and the structuration of the leisure market along class lines, one could hardly expect different outcomes.

On top of that, and this brings us to the final point, the described institutional transformation of the literary field comes at the cost of reconceptualizing what was once known as "literature" - a public and immanently social practice of creativityas creative writing - primarily a practice of individual expression, and a service to be offered on the market. In his innovative critical study of American literature of the second half of the twentieth century, The Program Era: Postwar Fiction and the Rise of Creative Writing, Mark McGurl writes about quite a different context in which the creative writing program has not only had a long and rich history, but has proven to be the decisive cultural-institutional transformation of at least the past half-century. McGurl commends the creative writing program for "attempts to realize a diverse aesthetic democracy" in contrast to various exclusivist or esoteric conceptions of literature also present in the field. Simultaneously, however, he is aware of the possibility that the program "represents a further incursion of consumerism into the academy, a ballooning enterprise of mass vanity and anti-intellectualism" (74). In the postsocialist Croatian context, where creative writing is imported as a type of complex cultural product from a core country and preceded by no serious self-reflection or principled reform that would pave the way for a mode of its implementation that would be more open to considerations of public interest, cultural development, or pedagogical creativity, its effects are regrettably closer to the latter. In this context, as I have tried to show, the modernist idea of autonomous cultural production that was given early institutional form in the Yugoslav socialist period is jeopardized precisely by the implementation of the post-socialist creative writing program, despite that 
model's origins in early twentieth-century democratic attempts to progressively transform higher education in the United States. At a time when equivalent changes are eroding the system of public education and other historical gains achieved in myriad democratic struggles across decades and centuries, it is necessary to observe the dangers of the structural logic of such supposedly desirable developments as they systemically lead to the bureaucratization and elitization of practices affected by them. This is in a completely opposite direction, in other words, from where the now scorned modernist innovations of Yugoslav self-governing socialism were supposed to lead to.

\section{Towards a Creative Institutionality}

Having all this in mind, we can end with a quite banal conclusion: if a society aims to produce culture and literature as a living social practice, accepted, recognizable, and accessible to all, the institutional reconfiguration of the field within which it is produced needs to be carried out in accordance with those principles (let us for now put aside the fact that it is first necessary to politically create the social conditions in which something like that would be possible). Interesting attempts to grapple with similar ideas can be found in recent Yugoslav history, and as much as possible should be learned from them by those trying to battle the radical neglect of traditions and experiences of socialist modernity inaugurated with the restoration of capitalism during the post-socialist transition, and the global ideological triumph of capitalist universality. One of the consequences of this triumph seems to be the opportunistic abandoning of the principle of artistic autonomy, a development that should be considered rather suspect, as it is, in this context, a sign of radical resignation to the heteronomy of capital. Lest I be misunderstood: certainly-literature is, besides being reading and writing, a social institution, and as such, it demands its own logistics and organizational framework; it does not emerge ex nibilo, absolutely free, spontaneous, and autonomous. And literary work, and cultural work more broadly, also involves institutional, pedagogical, and other social components, as well as a specific structural position within the broader system of capitalist social relations. So it is precisely from there that its immanent and undeniable political responsibility stems. The form of this responsibility, as developed in opposition to subsumption under capital throughout the past two centuries or so, has been the principle of autonomy. Unreflectively importing and copying institutional models from the dominant center to the immobilized periphery for commercial purposes, therefore, from the perspective of a cultural worker, means avoiding this key, immanent responsibility; it is no more than a sign of resignation to subsumption and heteronomy, a servile nod to the boss. Truly creative literature should be thought of as creative in its entirety-aesthetically, politically, institutionally. 


\section{Works Cited}

Bartolčić, Nenad, et al. Knjiga u fokusu: Potpora kreativnoj industriji - Stručna analiza $i$ preporuke za uredenje tržišta knjiga $i$ sirenje kulture citanja u RH. Knjižni blok inicijativa za knjigu, 2013.

Batuman, Elif. "Get a Real Degree." London Review of Books, vol. 32, no. 118, 2010, pp. 3-8, lrb.co.uk/v32/n18/elif-batuman/get-a-real-degree. Accessed 23 Feb. 2016.

Bourdieu, Pierre. The Rules of Art: Genesis and Structure of the Literary Field. Translated by Susan Emanuel, Stanford UP, 1995.

Buden, Boris. Barikade. Arkzin, 1996.

Croatia, Republic of. Croatian Competition Agency. "Rješenje Agencije za zaštitu tržišnog natjecanja Klasa: UP/I 430-01/2008-03/05 od 17. travnja". Narodne novine 47/2008, narodne-novine.nn.hr/clanci/sluzbeni/2008_04_47_1601.html. Accessed 3 Mar. 2016.

—. "Rješenje Agencije za zaštitu tržišnog natjecanja, klasa: UP/I 430-01/2011-03/001, urbroj: 580-03-11-43-02 od 10. veljače 2011.", Narodne novine 23/2011, narodne-novine.nn.hr/clanci/sluzbeni/full/2011_02_23_493.html. Accessed 3 Mar. 2016.

Čegec, Branko. Presvlačenje avangarde: 7 tesktova o književnosti avangarde i postavangardnih gibanja. Centar društvenih djelatnosti, 1983.

Domazet, Tihomir. "Investicije kao uzrok krize i investicije u novoj ekonomici rasta i pune zaposlenosti." Ekonomija/Economics, vol. 21, no.1, 2014, pp. 1-26.

Duda, Dean. Hrvatski književni bajkomat. Disput, 2010.

Flaubert, Gustave. Selected letters. Translated by Geoffrey Wall, Penguin Books, 1997.

Kardelj, Edvard. Izbor iz dela V-Društvena kritika. Izdavački centar Komunist, 1979.

Kolanović, Gordana. "Marinko Koščec: Pisanje je umjetnost koja se izučava i usavršava." tportal.hr, 25 Jan., 2013, tportal.hr/kultura/clanak/pisanje-je-umijece-koje-seizucava-i-usavrsava-20130110. Accessed 15 Feb. 2016.

Krleža, Miroslav. "Govor izrečen 5. X. 1952. na Trećem kongresu Saveza književnika Jugoslavije (5-7. X. 1952).” Hrvatska književna kritika 10: Suvremena kritika, edited by Šime Vučetić, Matica hrvatska, 1960.

Mandić, Davor. "Studij pisanja i nakladništva: SPIN za pisce s diplomom." Novi list, 3 Jan., 2013, novilist.hr/Kultura/Knjizevnost/Studij-pisanja-i-nakladnistva-SPINza-pisce-s-diplomom. Accessed 1 Mar. 2016.

McGurl, Mark. The Program Era: Postwar Fiction and the Rise of the Creative Writing. Harvard UP, 2009.

— . "A Response to Elif Batuman." markmcgurl.com, 10 Oct., 2010, markmcgurl.com/ response_to_Batuman.html. Accessed 23 Feb. 2016.

Mikuličin, Ivana. "Prodaja knjiga u godinu dana pala je 50\%." Jutarnji list, 22 Oct. 2012, jutarnji.hr/kultura/knjizevnost/prodaja-knjiga-u-godinu-dana-pala-je50/1355970/. Accessed 1 Mar. 2016. 
Mikulić, Borislav. Kroatorij Europe: Filosofistička kronika druge hrvatske tranzicije u 42 slike. Demetra, 2006.

Perišić, Robert. "Književnost i kapital - Dudeki na tržištu”. Kritična masa. kriticnamasa. com/item.php?id=124. Accessed 26 Feb. 2016.

Pintarić, Jadranka. "Razgovor s Nikolom Petkovićem.” Zarez, 1 Jun. 2007, zarez.hr/clanci/razgovor-s-nikolom-petkovicem. Accessed 26 Feb. 2016.

Piteša, Adriana. "PDV na knjige - sigurna smrt nakladnika!" Jutarnji list, 3 Jan., 2013, jutarnji.hr/kultura/art/pdv-a-na-knjige-sigurna-smrt-nakladnika/1183244/. Accessed 1 Mar. 2016.

Špiranec, Kristina. "Kreativno pisanje". Tema: časopis za knjigu. vol. 10, no. 1/2, 2013, pp. 9-31. 